A Simple Guide to Modern Valency Theory By G. I. Brown. Pp. ix +174. (London, New York and Toronto : Longmans, Green and Co., Ltd., 1953.) 12s. $6 d$. net.

$\mathrm{T}$ $\mathrm{HE}$ author of this book, a master at Eton College, in framing this concise account of modern ideas on valency acknowledges his debt to the writings of Sidgwick and Linus Pauling. His early chapters contain a good account of the history of valency and of its classical conception. Then follow chapters severally dealing with the covalent, electrovalent and dative bonds and with experimental methods of investigating these linkages. In these chapters Mr. Brown explains clearly and adequately the modern ideas more fully than in the ordinary advanced text-book of chemistry.

Dr. L. E. Sutton, himself a well-known worker in this field, says in the foreword: "present day valency theories concern a very wide range of phenomena... [and] cover the whole discussion of potential energy and configuration for atomic, molecular, and intermolecular systems". This conception of the place of valency accounts for chapters on internal dimensions of crystals and molecules; simple examples of resonating molecules; hydrogen and the hydrogen bond; and molecular orbitals. These chapters are well written, and the new terms and ideas are carefully explained by a writer who obviously has a grip of his subject. Nevertheless, I believe that more applications of the new knowledge would improve the book. The theory of molecular orbitals has been used advantageously in promoting an understanding of bonding in organic molecules. The author devotes a whole chapter to this theory, but uses it only to explain why oxygen is paramagnetic. Again, the preface states that the book is intended for sixthform pupils and for older chemists interested in modern developments. Teachers among these 'older chemists' will be disappointed to find that the author touches but lightly on the time-honoured valency difficulties connected with nitric oxide, carbon monoxide and hydrogen peroxide; also, they will find no answer to the alert sixth-former who asks why does the atom of copper procure valency electrons from the penultimate shell? Still, this is a minor criticism; the author has written a good concise account of modern valency. G. FowLiES

Introduction to Tensors, Spinors, and Relativistic Wave-equations

(Relation Structure.) By Prof. E. M. Corson. Pp. xiii +221 . (London and Glasgow : Blackie and Son, Ltd., 1953.) 55s. net.

UANTUM theory of fields has developed along two main lines : one concerning itself with the mathematical basis of the subject; the other, more particularly with the relation of its predictions to experiment. In this volume, Prof. E. M. Corson addresses himself to a unified survey of the first development.

The book starts with a review of tensor and spinor analysis. The canonical formalism and the conservation laws of field theory are considered next, followed by a chapter on relativistic wave equations. The elimax of the theoretical development comes with the fifth chapter, where the basis of the theory is sought in abstract algebra and group theory. In the author's words, "here the physicist may find the answers as to how and why a particular covariant formalism is suitable for the description of particles of given spin, and how and why the so-called field aspect of given genus of particles is related to the so-called particle aspect".

The book is by no means easy to read, for considerable familiarity with the concepts of modern algebra is assumed. But to read through with Prof. Corson is an adventure of discovery-a discovery of some of the profoundest ideas in theoretical physics, presented with rare understanding and logical clarity. There is no mention of developments after 1947-possibly, with a gain in the permanent value of the book.

Abdos Salam

\section{The Chemical Structure of Proteins}

Edited by G. E. W. Wolstenholme and Margaret P. Cameron. (A Ciba Foundation Symposium.) Pp. xii $+222+6$ plates. (London: J. and A. Churchill, Ltd., 1953.) 25s. net.

THIS is a record of a Ciba Foundation Symposium

held in London in December 1952. It contrins about seventeen papers by recognized authorities and verbatim reports of very frank and illuminating discussions on them. The volume thus contains much interesting reading for all who are interested in protein structure. One might, however, be tempted to question whether publication of these symposia, however interesting they may have been, is in every case necessary. For topies which are not frequently reviewed there is much to be said for publication; but in a much-cultivated field like the structure of proteins, in which three symposia were held within a short period, to a considerable extent with the same participants, which have all been published, there is a good deal of overlapping.

One can sympathize with the desire of the organizers and participants of such conferences to see their news and views dispersed as widely as possible ; and readers who have time will undoubtedly find much that is of great interest. But the burden of coping with all such reports is becoming very great, and organizers might try to ensure that the collection they offer will be to a reasonable extent unique.

$$
\text { J. B. }
$$

\section{Weed Control in Farm and Garden}

By Stephen J. Willis. (Agricultural and Horticultural Students Series.) Pp. $184+6$ plates. (London: Vinton and Company, Ltd., 1954.) $8 s .6 d$. net.

$\mathbf{T}^{\mathrm{T}}$ is several years since the appearance of any British book which deals with all aspects of weed control, so that this small volume will be welcomed not only by the students to whom it is primarily addressed but also by many farmers and growers. Although the emphasis is essentially practical, sufficient discussion of basic principles is included to permit intelligent application of control methods, and the result is a well-bslanced account of modern techniques.

The first four chapters are concerned with the biology of weeds and the role of hygiene and cultural practice in their prevention. In the main body of the text available chemicals are described, weed responses tabulated and recommendations given for treatment of the various agricultural and horticultural crops. Spraying and dusting machinery is briefly discussed, and special methods for the control of certain perennial weeds and cryptogams outlined. Common and scientific names of weed species and formulæ of herbicides are listed in appendixes, while technical terms are explained as they occur. There is a good index, and the price seems very reasonable. 